\title{
LATIHAN MENIUP BOLA PINGPONG DALAM PENINGKATAN PENGUCAPAN KONSONAN BILABIAL PADA ANAK TUNARUNGU KELAS D2/B DI SLB B/C PARAMITA GRAHA BANJARMASIN
}

\author{
Fithri Aulia Azizah \\ SLB B/C Paramitha Graha Banjarmasin, Kalimantan Selatan \\ Email: afithri@rocketmail.com
}

\begin{abstract}
Abstrak
Selama organ bicaranya masih baik, hal ini tidak menutup kemungkinan seorang tunarungu dapat berbicara. Siswa tunarungu terkadang dapat menyebutkan identitas dirinya, namun pengucapan konsonan yang tidak terdengar jelas dan hampir hilang. Kemampuan bicara tunarungu sering terjadi kesalahan yang muncul akibat dari terganggunya pernapasan yang sering tidak digunakan dalam berbicara sehingga menjadi kaku. Perlu adanya latihan pernapasan sebelum melakukan tahap lanjutan bicara anak tunarungu yaitu latihan meniup secara letupan dengan menggunakan media bola pingpong. Tujuan penelitian adalah untuk mengetahui peningkatan pengucapan konsonan bilabial /b/ melalui latihan meniup bola pingpong. Metode yang digunakan adalah eksperimen, dengan pola Single Subject Research (SSR) desain A-B-A. Data yang dikumpulkan berupa data kuantitatif yang diperoleh dari tes perbuatan dan dokumentasi yang divisualisasikan melalui grafik garis. Hasil penelitian menunjukkan bahwa latihan meniup bola pingpong dapat meningkatkan pengucapan konsonan bilabial /b/ pada anak tunarungu kelas D2/B di SLB B/C Paramita Graha Banjarmasin.
\end{abstract}

Kata Kunci: latihan meniup, konsonan bilabial, anak tunarungu.

\begin{abstract}
As long as the speech organs are fine, there is a possibility for hearing-impaired students to be able to speak. Hearing-impaired students sometimes can mention their name, but the consonant pronunciation is not clear and almost disappeared. Hearing impaired speech skills often occur errors that arise due to the disruption of breathing which is often not used in speech so it becomes rigid. Breathing exercises are needed before the next stage of speech is hearing impaired to the child, which is blowing exercises by using a ping pong ball media. The purpose of this study is to determine the increase in pronunciation of bilabial consonants / $b$ / through pingpong ball blowing exercises. The method used is an experiment, with a Single Subject Research (SSR) design pattern A-B-A, in the form of quantitative data obtained from an act and documentation test, which is visualized through a line graph. The results showed that the practice of blowing pingpong balls can improve the pronunciation of bilabial consonants / b / in hearing impaired children of class D2 / B in SLB B / C Paramita Graha Banjarmasin.
\end{abstract}

Keywords: blowing exercises, bilabial consonants, hearing impaired children 


\section{PENDAHULUAN}

Menurut para pakar (Haenudin, 2013; Mansell, 2010; Nakken dan Vlaskamp, 2007; Poppes, Van der Putten, dan Vlaskamp, 2010) anak tunarungu adalah anak yang mengalami kekurangan atau kehilangan kemampuan pendengaran, baik sebagian atau seluruhnya, akibat tidak dapat menggunakan alat pendengarannya di kehidupan sehari-hari, maka berdampak pada kehidupannya secara kompleks terutama kemampuan berbahasa sebagai alat komunikasi.

Komunikasi merupakan suatu hal terpenting bagi kehidupan manusia. Pada kenyataannya tidak semua manusia dapat berkomunikasi dengan baik sesuai hakikat berkomunikasi pada umumnya yang menggunakan bahasa verbal dengan tata bahasa dan vokal yang jelas. Betapa pentingnya fungsi dari berbahasa lisan sebagai alat komunikasi, maka di sekolah diajarkan mata pelajaran Bahasa Indonesia tentang berbahasa dan berkomunikasi dengan melalui empat aspek yaitu menyimak, berbicara, membaca, dan menulis.

Kemampuan berbahasa lisan atau bicara setiap orang tidaklah sama. Tunarungu merupakan salah satu individu yang mengalami masalah dalam berbicara. Akibat dari keterbatasan kemampuan mendengar membuat mereka hanya sedikit memperoleh informasi auditif dari lingkungannya, hal ini yang membuat mereka tidak tahu dan merasa bingung untuk mengungkapkan sesuatu dengan berbicara. Sehingga, organ bicara mereka jarang digunakan dan menjadi kaku, demikian juga berdampak pada pernapasan yang juga jarang digunakan untuk berbicara akan terganggu. Sering dijumpai bicara anak tunarungu terdengar monoton, kadang melengking atau apa yang diucapkannya tidak sesuai dengan maknanya.

Berdasarkan hasil observasi peneliti di SLB B/C Paramita Graha Banjarmasin, peneliti bertemu dengan seorang anak tunarungu yang mengenalkan dirinya dengan berbahasa lisan sambil berbahasa isyarat. Pertama kali bertemu dengan seseorang yang belum dikenal tentunya ingin mengetahui identitas satu sama lain, maka hal yang paling utama dilakukan yaitu akan memberitahu nama sebagai identitas utama seseorang agar saling mengenal. Peneliti tertarik dengan anak tersebut, dia masih memiliki sisa pendengaran, namun perkembangan bahasa lisannya masih kurang atau belum berkembang, ada salah satu bunyi konsonan yang pengucapannya tidak terlalu jelas dan hampir hilang, konsonan tersebut ialah konsonan bilabial /b/.

Pengucapan konsonan anak tunarungu perlu dilakukan latihan, untuk membantu dia berkomunikasi dalam kehidupan sehari-harinya dan minimal anak tunarungu bisa menyebutkan nama lengkapnya sebagai identitas diri yang lebih jelas tanpa ada pengucapan konsonan yang hilang agar lawan bicaranya dapat memahami apa yang dia sampaikan.

Selama tidak ada memiliki hambatan lain yang berhubungan dengan organ artikulasi yaitu lidah, gigi, bibir, gusi, lelangit, rongga hidung, dan pita suara, kemampuan bicara anak tunarungu masih dapat dikembangkan. Namun, kebanyakan dari mereka tidak dapat berbahasa lisan bukan karena organ artikulasinya yang mengalami kerusakan. Tetapi, karena tidak diberikan stimulus atau latihan dari awal pada masa usia perkembangan untuk menggunakan bahasa atau komunikasi lisan. Salah satu upaya untuk membentuk komunikasi tunarungu sesuai dengan hakikat berkomunikasi yaitu dengan mengembangkan potensi dasar dalam berbahasa lisan melalui pembinaan bicara.

Sebelum memasuki pembinaan dalam bicara maka perlu adanya bentuk kegiatan persiapan bicara melalui latihan meniup, berkaitan dengan anak tunarungu yang memiliki karakter fisik yaitu 
pernapasannya pendek dan terganggu untuk mengeluarkan suara. Pernapasan memiliki peranan utama dalam bicara. Salah satu kesalahan pengucapan anak tunarungu adalah pengucapan konsonan bilabial letupan bersuara /b/. Tujuan dari latihan pernapasan yaitu untuk meningkatkan kemampuan pengucapan konsonan bilabial dengan latihan meniup bola pingpong dalam saluran pipa paralon.

Latihan meniup bola pingpong merupakan latihan pernapasan dalam meningkatkan kemampuan pengucapan konsonan bilabial /b/ melalui latihan meniup secara letupan. Media bola pingpong, yang memiliki ukuran kecil, ringan, sisinya bulat dan rata dapat mudah menggelinding bila ditiup secara letupan. Kekuatan pernapasan anak dapat dilihat dari jauh dekatnya hasil tiupan anak secara letupan pada bola pingpong. Latihan ini untuk memperkuat otot-otot pernapasan sebagai bentuk menunjang peningkatan pengucapan konsonan bilabial /b/. Dengan adanya latihan pernapasan meniup secara letupan terhadap bola pingpong diharapkan anak dapat mengatasi hambatan dalam pengucapan konsonan bilabial /b/.

\section{Tinjauan Pustaka}

Menurut para pakar (Humaera, 2017; Indriati, 2015; Isnendes, 2005; Sunanik, 2013; Yanti, 2012) bahwa bicara atau wicara merupakan kemungkinan-kemungkinan manusia dalam pengucapan bunyibunyian bahasa melalui organ-organ artikulasi atau organ bicara. Jadi, bicara atau wicara dapat disimpulkan bahwa manusia dapat mengeluarkan suatu ide, pendapat, pemikiran, perasaan ataupun hal lainnya yang dapat diungkapkan oleh seorang individual melalui bunyi bahasa yang dikeluarkan dari organ artikulasinya.

Karakteristik bicara anak tunarungu salah satunya berhubungan dengan pernapasan, yakni pernapasan anak tunarungu pendek dan mengalami gangguan untuk bicara, kelainan bicara ditandai dengan kurang benar dan kurang kuatnya pernapasan untuk membentuk bunyi konsonan. Kesalahan pengucapan mereka yaitu bunyi bahasa yang tidak jelas pada saat pengucapan.

Program Khusus Dalam Pendidikan Anak Tunarungu. Program khusus dalam pendidikan anak tunarungu salah satunya ialah Bina Bicara, menurut para pakar (Arifin, 2013; Depdikbud, 2000; Purbaningrum, 2008; Sadjaah \& Sukarja, 1995), bina bicara terdiri dari kata bina, dan bicara. Pengertian dari bina adalah usaha, tindakan dari kegiatan yang dilaksanakan secara berdaya guna dan berhasil guna memperoleh hasil yang lebih baik. Sedangkan bicara yaitu berkata, berbicara, melahirkan pendapat. Bina bicara merupakan suatu tindakan yang secara efektif dapat memperoleh hasil bicara lebih baik. Tindakan yang dilakukan untuk pembinaan bicara disesuaikan dengan gangguan bicara yang dialami anak tunarungu yang berdasarkan dari hasil asesmennya.

Prinsip Pembelajaran Anak Tunarungu. Prinsip pembelajaran anak tunarungu bermacam-macam menurut Rahman (2018) yakni prinsip: 1) Prinsip Keterarahan wajah, 2) Prinsip Keterarahan suara, dan 3) Prinsip Keperagaan.

Konsonan Bilabial. Menurut Sadjaah dan Sukarja (1995) bunyi bahasa konsonan terbentuk karena adanya aliran udara dari paru-paru yang dihalangi oleh salah satu alat ucap yang ada dalam tenggorokan atau rongga mulut. Rintangan udara itu ada yang seluruhnya dan ada pula yang hanya sebagian dengan menggetarkan udara. Sedangkan, bilabial berasal dari kata bi (dua) dan labial (bibir). Jadi, konsonan bilabial merupakan bunyi bahasa yang keluar dari dua bibir dengan beberapa bunyi konsonan bilabial yaitu /p/, /b//m/, dan /w/. 
Hambatan tersebut dapat ditimbulkan daripada sebagian alat bicara, seperti hambatan pada kedua bibir untuk bunyi /b/, hambatan ditimbulkan dari ujung lidah dengan menyentuh belakang gigi depan atas pada bunyi /t/ dan sebagainya.

Konsonan bilabial ialah salah satu dari beberapa konsonan yang terdiri dari /p/, /b/, /m/, dan /w/. Latihan pengucapan konsonan bilabial dapat dilakukan dengan berbagai latihan pengucapan. Untuk pengucapan /b/ dapat dibentuk melalui latihan meniup atau simulasi pernapasan untuk meningkatkan kemampuan wicara anak tunarungu.

Pengucapan Konsonan Bilabial /b/ Anak Tunarungu. Pengucapan konsonan dan vokal yang salah akan berpengaruh kepada bicara anak tunarungu. Anak tunarungu sering melakukan kesalahan dalam mengucapkan konsonan maupun vokal yaitu dengan menghilangkan, mengganti, menambah, dan atau mengacaukan konsonan atau vokalnya. Pada konsonan bilabial/b/, anak tunarungu sering melakukan kesalahan dalam pengucapannya, dihilangkan atau mungkin diganti dengan konsonan lainnya yaitu paling sering anak tunarungu menggantinya dengan konsonan $/ \mathrm{p} /$.

Kesalahan-kesalahan seperti ini seharusnya diperbaiki sedini mungkin, agar nantinya perkembangan bahasa dan kemampuan bicara anak dapat berkembang ketika ia semakin dewasa. Semakin dewasa anak apabila sering dilakukan latihan dari usia dini, maka pembentukan kata-kata akan semakin mudah baginya. Kesalahan pengucapan anak tunarungu dapat diperbaiki melalui latihan-latihan yang menunjang perbaikan pengucapan konsonan bilabial /b/ yaitu dengan salah satu latihan yang diduga dapat memperbaiki dan meningkatkan pengucapan konsonan bilabial /b/ yakni dengan latihan pernapasan dengan meniup secara letupan terhadap bola pingpong.

Latihan Meniup Bola Pingpong. Latihan meniup terdiri dari dua kata yaitu latihan dan meniup. Kata latihan berasal dari kata 'latih' yang merupakan suatu rangkaian dalam sebuah peristiwa untuk mempengaruhi seseorang agar lebih mudah mencapai tujuannya, dengan kegiatan yang tersusun secara sistematis sehingga dapat mencapai rancangan dan pengembangan suatu pembelajaran. 'Latih' merupakan suatu perolehan dari yang belum bisa menjadi bisa dan membiasakan diri agar mempunyai kemampuan untuk melakukan sesuatu, sedangkan "latihan" ialah hasil dari berlatih yang diikuti sudah lebih baik dari sebelum melakukannya (Sadja'ah, 2005). Sedangkan, meniup berasal dari kata "tiup" yaitu suatu pergerakan yang mengalir dengan cepat tentang angin dan udara.

Latihan pernapasan berhubungan dengan pelajaran artikulasi dalam bina wicara. Pembinaan bicara merupakan bentuk kegiatan dalam persiapan bicara yang dapat dilakukan dengan bermacam-macam bentuk kegiatan yaitu dengan melakukan senam mulut melalui permainan, meraban melalui permainan (permainan rabanan), bersenandung dengan konsonan tertentu misal /m/, /n/ maupun bentuk konsonan lainnya, pelemasan otot muka, laring, leher, dan lainnya, serta latihan meniup dengan manipulasi konsonan bilabial (Sardjono \& Kusumo, 2005).

Pada umumnya anak tunarungu tidak atau bahkan kurang dalam mengatur pernapasannya dengan baik pada saat bicara, disebabkan sejak kecil paru-paru anak tunarungu kurang terlatih dalam mengatur pernapasannya untuk kepentingan bicara. Maka dari itu, pernapasan anak tunarungu perlu dilakukan latihan terlebih dahulu sebelum masuk ke dalam pengajaran bina bicara lebih lanjut. Usaha perbaikan bicara anak tunarungu akan tidak efektif apabila pernapasannya belum benar.

Latihan pernapasan dengan meniup secara letupan dapat dilakukan dengan media bola pingpong yang memiliki ukuran kecil, ringan, sisinya bulat dan rata dapat mudah menggelinding bila ditiup secara 
letupan. Kekuatan pernapasan anak dapat dilihat dari jauh dekatnya hasil tiupan anak secara letupan pada bola pingpong. Latihan ini bertujuan untuk memperkuat otot-otot pernapasan sebagai bentuk untuk menunjang peningkatan pengucapan konsonan bilabial/b/. Dengan adanya latihan pernapasan meniup secara letupan terhadap bola pingpong diharapkan anak dapat mengatasi hambatan dalam pengucapan konsonan bilabial /b/.

Latihan pernapasan dengan meniup secara letupan terhadap bola pingpong dilakukan di dalam pipa paralon berukuran 1,5 inci yang di belah menjadi dua bagian tengahnya dengan panjang $40 \mathrm{~cm}$. Salah satu ujung paralon tersebut ditutup, agar bola pingpong tidak menggelinding keluar dan agar anak tunarungu mengetahui hasil tiupannya mencapai batas atau belum. Penggunaan paralon dikarenakan alas paralon merupakan tekstur yang halus yang memudahkan bola menggelinding, dan paralon memiliki sisi kanan dan kiri sehingga bola pingpong tidak kesana kemari. Selain itu, paralon yang dibuat tidak membahayakan anak, praktis, mudah disimpan dan dibawa kemana-mana.

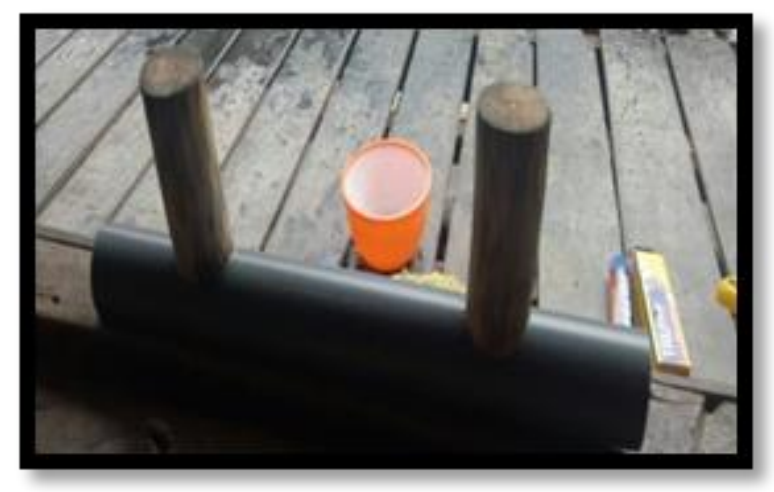

Gambar 1. Media Meniup Bola Pingpong

a. Alat dan Bahan Pembuatan Media:

\begin{tabular}{ll}
\hline \multicolumn{1}{c}{ Alat } & \multicolumn{1}{c}{ Bahan } \\
\hline Gergaji pipa & Pipa paralon \\
\hline Gergaji kayu & Lem pipa \\
\hline Penggaris & Kayu \\
\hline Pensil & Kuas dan Cat \\
\hline- & Bola pingpong ukuran $40 \mathrm{~mm}$ \\
\hline
\end{tabular}




\section{Langkah-Langkah Pembuatan Media}

Adapun langkah-langkah dalam pembuatan media meniup bola pingpong di dalam pipa paralon:

1. Siapkan pipa paralon dengan diameter 1.5 inci dengan panjang $40 \mathrm{~cm}$.

2. Setelah itu bagilah dua diameter pipa paralon tadi dengan dua bagian dan beda sisi, satu sisi lebih banyak karena untuk menjadi penyangga bola agar tidak keluar dari pipa.

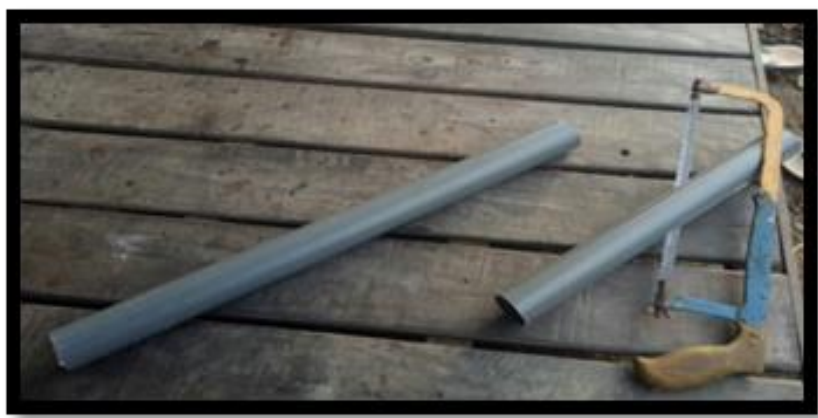

Gambar 2. Proses Memotong Pipa Paralon

3. Persiapkan juga kaki untuk menopang bagian bawah pipa agar nanti pada saat melakukan latihan, media dapat seimbang. Kaki terbuat dari Kayu dengan panjang $10 \mathrm{~cm}$, untuk menopang diperlukan dua kaki dari kayu tersebut.

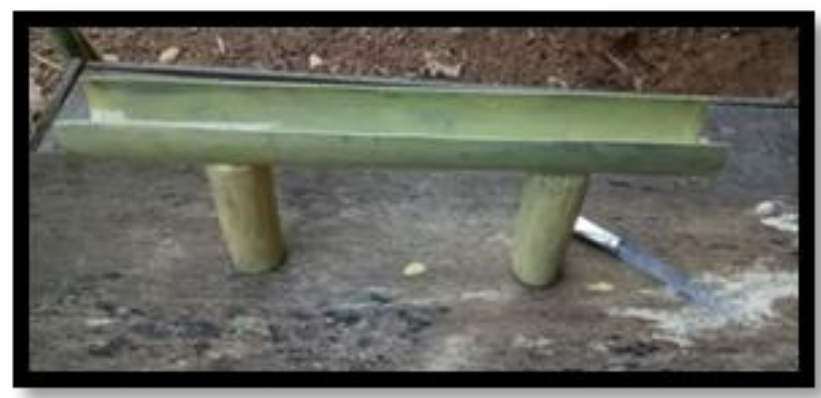

Gambar 3. Kaki Penopang Media

4. Terakhir, untuk membuat media lebih menarik maka catlah dengan sesuai warna kesukaan

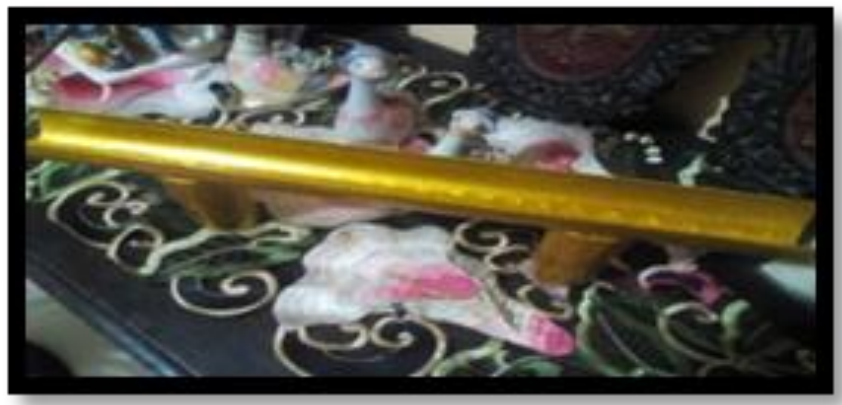

Gambar 4. Proses Pengecatan Media 


\section{b. Cara Penggunaan Media:}

1. Lakukanlah asesmen terlebih dahulu untuk mengetahui kondisi dan kemampuan anak.

2. Sebelum memulai latihan, kondisikan anak senyaman mungkin, tidak dalam keadaan menegangkan atau sebagainya yang akan mempengaruhi proses berjalannya latihan,

3. Pelatih/ Guru mempersiapkan alat dan bahan (lembar pencatatan data, cermin, dan media),

4. Anak dipersilahkan melihat media yang akan digunakan,

5. Duduklah di samping anak dan ajak dia menghadap ke arah cermin yang sudah di sediakan,

6. Pelatih/ Guru memperkenalkan ciri-ciri pengucapan konsonan bilabial /b/ kepada anak dengan menghadapkan telapak tangan anak ke depan bibir pelatih pada saat mengucapkan kata "beh" secara letupan,

7. Anak diminta untuk merasakan letupan yang keluar dari bibir pelatih saat mengucapkan konsonan bilabial /b/ dan memperhatikan bentuk bibir pelatih waktu pengucapan,

8. Anak diminta untuk mencoba hal yang sama dalam mengucapkan konsonan bilabial /b/ seperti yang sudah dilakukan oleh pelatih dan menghadapkan telapak tangannya ke depan bibirnya sendiri,

9. Lakukanlah hal ini secara berulang antara pelatih dan anak, sampai anak memahami pengucapan yang benar dan sama dengan pelatih,

10. Pelatih/ Guru memperkenalkan kepada anak media secara detail bahwa media akan menjadi alat untuk proses latihan pengucapan secara letupan,

11. Pelatih/ Guru mempraktikkan cara menggunakan media dengan menaruh bola pingpong di bagian permukaan pipa atau di bibir pipa, Ketika Pelatih/Guru mengucapkan kata "beh" secara letupan, bola pingpong yang berada di dalam pipa paralon akan bergerak,

12. Pelatih/ Guru memberikan pemahaman kepada anak apabila letupan semakin kuat maka jarak bola akan semakin jauh dan hal tersebut akan semakin bagus begitupun sebaliknya,

13. Berikanlah pemahaman kepada anak secara berulang-ulang sampai anak memahaminya,

14. Lakukan praktik ini selama 10 menit, hingga pernapasan anak mulai membaik dan siap untuk melakukan tes pengucapan konsonan bilabial/b/ dengan kartu kata,

15. Setelah melakukan kegiatan tersebut, guru memberikan perintah kepada anak untuk melanjutkan kegiatan selanjutnya,

16. Pelatih/ Guru mempersiapkan lembar pencatatan data hasil tes setelah di berikan intervensi atau perlakuan melalui media,

17. Anak diminta mengucapkan kata dari kartu kata yang ditunjukan oleh guru yaitu kartu kata konsonan bilabial /b/ yang terletak di awal, di tengah, dan di akhir secara berututan,

18. Pelatih/ Guru memberikan reward (hadiah) ketika anak mampu melakukan semua tugas yang diperintahkan oleh guru,

19. Pelatih/ guru memberi penguatan, pesan moral agar rajin belajar dan mengakhiri pembelajaran dengan berdoa bersama. 
Tujuan penelitian ini yaitu untuk pembinaan wicara melalui latihan meniup bola pingpong dalam pembentukan konsonan bilabial /b/ pada anak tunarungu kelas D2/B di SLB B/C Paramita Graha Banjarmasin.

\section{METODE PENELITIAN}

Pendekatan dalam penelitian ini menggunakan pendekatan kuantitatif yaitu pendekatan yang berbentuk angka dan numerik. Pendekatan ini bersifat konfirmasi yaitu mengkonfirmasi antar teori dan kenyataan yang berdasarkan data ilmiah. Dalam penarikan kesimpulan pada penelitian kuantitatif bersifat deduktif yaitu menarik kesimpulan dari yang bersifat umum ke bersifat yang khusus.

\section{Jenis Penelitian.}

Jenis penelitian yang digunakan dalam penelitian ini adalah eksperimen dengan bentuk subjek tunggal atau yang lebih dikenal dengan single subject research (SSR). Penelitian dengan subjek tunggal ini fokus pada data individu sebagai sampel penelitian.

\section{Desain Penelitian.}

Desain penelitian subjek tunggal atau SSR terfokuskan pada data individu atau perseorangan sebagai sampel penelitian. Penelitian dengan subjek tunggal atau SSR ini menggunakan desain A-B-A, di desain ini setelah pengukuran pada kondisi intervensi (B) pengukuran pada kondisi baseline 2 (A2) diberikan. Penambahan kondisi baseline 2 (A2) ini dimaksudkan sebagai kontrol terhadap setelah diberikannya intervensi (B) sehingga keyakinan untuk menarik kesimpulan apakah terdapat hubungan fungsional antara variabel bebas dan variabel terikat lebih kuat. Menurut Sunanto, Takeuchi, and Nakata (2005) fase baseline adalah fase saat variabel terikat (target behavior) diukur secara periodik sebelum diberikan perlakuan tertentu. Dalam hal ini kejelasan pengucapan konsonan bilabial /b/ dengan pengaturan pernapasan anak tunarungu sebelum perlakuan dilakukan. Sedangkan fase intervensi adalah fase saat target behavior di observasi atau diukur selama perlakuan tertentu diberikan. Penelitian single subject research (SSR) dan desain penelitian A-B-A digambarkan grafik sebagai berikut:

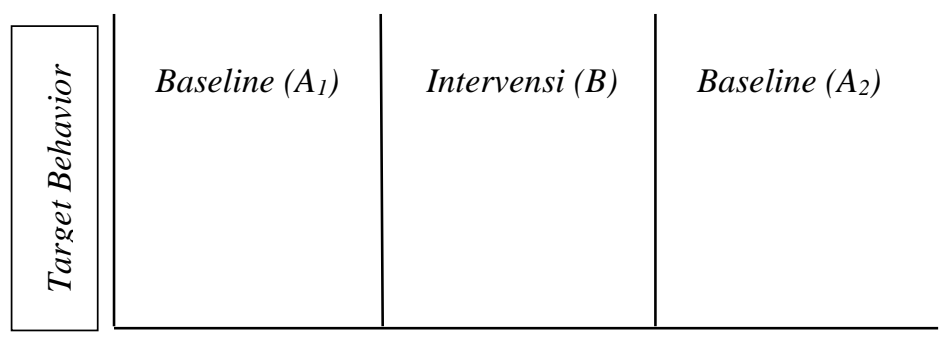

Sesi Waktu 
Keterangan:

A1 : Lambang dari garis (baseline 1), baseline dasar merupakan keadaan subjek sebelum mendapat intervensi. Dalam hal ini menyangkut pengucapan konsonan bilabial /b/ sebelum diberikan perlakuan dengan menggunakan kartu kata berisikata-kata yang mengandung konsonan bilabil /b/ yang letaknya berada di awal, di tengah, dan di akhir. Untuk mengetahui seberapa jauh kemampuan pengucapan konsonan bilabial/b/anak.

B : Data perlakuan/ intervensi yaitu suatu keadaan subjek diberi perlakuan dengan tujuan untuk membentuk konsonan bilabial /b/ melalui latihan meniup secara letupan pada bola pingpong.

A2 : Merupakan baseline 2, dengan pengulangan kondisi baseline dasar A1 yang dilakukan untuk mengetahui hasil intervensi yang diberikan kepada anak.

Tujuan menggunakan desain penelitian A-B-A adalah untuk mempelajari seberapa besarnya pengaruh dalam suatu perlakuan (intervensi) terhadap variabel yang diberikan kepada individu, dengan membandingkan kondisi baseline sebelum dan sesudah intervensi. Target dari penelitian ini yaitu meningkatkan pengucapan konsonan bilabial /b/ menggunakan latihan meniup secara letupan pada bola pingpong. Penelitian ini dilaksanakan di SLB B/C Paramita Graha Banjarmasin yang beralamat di Jl. Kelayan B, Gg. Sukaria Banjarmasin.

\section{Sistem Pencatatan Data.}

Menurut Sunanto, Takeuchi, dan Nakata (2005), Tawney dan Gast (n.d.), "secara garis besar ada tiga macam prosedur pencatatan data yang digunakan pada penelitian modifikasi perilaku, yaitu pencatatan data secara otomatis, pencatatan data dengan produk permanen, pencatatan data dengan observasi langsung. Dalam penelitian ini data yang ingin diketahui informasinya atau yang ingin diteliti adalah pencatatan dengan produk permanen yang disebut suatu hasil dari suatu tindakan atau perilaku yang dilakukan oleh anak. Pencatatan dengan produk permanen ini dilakukan terhadap variabel atau perilaku sasaran yang dihasilkan oleh anak dengan data yang dihasilkan secara langsung berada dalam dokumen tertentu, dalam penelitian ini adalah hasil dari perlakuan yang diberikan kepada anak dalam hal peningkatan pengucapan konsonan bilabial /b/. Pencatatan data yang dilakukan dalam penelitian ini adalah:

1. Tes: merupakan suatu alat maupun prosedur yang digunakan untuk mengetahui atau mengukur sesuatu yang sesuai dengan yang sudah ditentukan dalam proses penelitian baik dengan caranya, suasana maupun aturan-aturannya (Arikunto, 2019). Tes dalam penelitian ini menggunakan tes perbuatan dengan instrumen yang sudah dibuat untuk mengetahui kemampuan pengucapan konsonan bilabial /b/ melalui observasi. Tes perbuatan dengan pengucapan konsonan bilabial /b/ di awal, di tengah, dan di akhir kata sebanyak 30 item berupa kartu kata. Tes dalam penelitian ini untuk mengukur kemampuan pengucapan konsonan bilabial /b/ anak sebelum dan setelah mendapatkan latihan meniup secara letupan terhadap bola pingpong.

2. Dokumentasi: ialah data-data yang terkumpul dengan data yang konkret didapatkan melalui pencatatan data sebagai bentuk bukti. kemampuan pengucapan konsonan bilabial /b/ anak tunarungu yang menjadi subjek penelitian, foto-foto proses penelitian, administrasi yang sesuai dengan penelitian mengenai anak tunarungu yang dijadikan subjek penelitian. Bentuk sebuah bukti dari hasil penelitian serta dapat memberikan keterangan terkait penelitian. 


\section{Teknik Analisis Data}

Metode yang digunakan dalam menganalisis data hasil penelitian ini dengan menggunakan pengamatan langsung terhadap data yang ditampilkan dalam bentuk grafik. Kriteria penilaian yang digunakan dalam mencatat data kemampuan pengucapan konsonan bilabial /b/ adalah:

a. Skor 1 diberikan apabila anak mampu mengucapkan konsonan bilabial/b/yang terletak pada masing-masing kata di awal, di tengah dan di akhir, maka skor satu. Konsonan lain tidak berpengaruh yang diteliti hanyalah konsonan bilabial /b/.

b. Skor 0 diberikan apabila anak dalam mengucapkan konsonan bilabial /b/ pada kata tidak terdengar sama sekali atau mengganti dengan konsonan lain selain konsonan /b/.

Maka untuk mendapatkan hasil data dapat dirumuskan sebagai berikut:

$$
P=\frac{f}{n} \times 100 \%
$$

Keterangan:

$P=$ Hasil persentase, rata-rata kemampuan pengucapan konsonan bilabial /b/ anak tunarungu

$f=$ Skor yang diperoleh anak tunarungu dalam pengucapan konsonan bilabial /b/

$n=$ Skor maksimal dalam pengucapan konsonan bilabial $/ \mathrm{b} /$.

\section{HASIL DAN PEMBAHASAN}

\section{Hasil Penelitian}

Baseline $1\left(\mathbf{A}_{1}\right)$. Penelitian tahap yang pertama baseline $1\left(\mathrm{~A}_{1}\right)$ sebagai bentuk mengetahui kemampuan awal anak sebelum dilakukan intervensi (B). Tahap ini dilakukan pengumpulan data anak sebanyak lima (5) sesi. Hasil kemampuan anak dalam pengucapan konsonan bilabial/b/ pada tahap ini sesi ke-1 memperoleh skor 10 dengan persentase 33\% pengucapan anak masih belum jelas dan terdengar masih samar. Sesi ke-2 s.d sesi ke-5 memperoleh skor 9 dengan persentase 30\%, kemampuan pengucapan konsonan bilabial /b/ dengan hasil yang sama, mengalami penurunan dibandingkan sesi 1 , hal ini disebabkan karena pengaturan napas yang dikeluarkan anak pada saat pengucapan masih belum stabil. Peneliti memperhatikan pengucapan konsonan bilabial /b/ yang diucapkan anak masih terdengar tipis, tanpa letupan, dan napas yang di keluarkannya pendek dan belum terkontrol dengan baik. Sehingga, dalam kemampuan pengucapan konsonan bilabial /b/ napasnya masih tersendat-sendat, dan putus-putus.

Intervensi (B). Setelah mengetahui kemampuan anak pada tahap baseline $1\left(\mathrm{~A}_{1}\right)$ maka tahap selanjutnya adalah tahap intervensi (B). Tahap ini dilakukan sebagai bentuk pemberian perlakuan terhadap anak untuk mengetahui pengaruh setelah diberikan perlakuan. Pada tahap ini anak diperkenalkan dengan media untuk latihan meniup bola pingpong dalam pipa paralon dilakukan sebanyak enam (6) sesi. Dalam tahap ini anak diberikan perlakuan dengan pengucapan konsonan bilabial /b/ diperintahkan untuk meniup dengan letupan terhadap bola pingpong yang terletak di dalam pipa paralon dengan mengucapkan kata "beh" atau meniup secara letupan yang akan sudah diajarkan oleh peneliti sebelum memulai perlakuan. Hasil kemampuan anak dalam kemampuan pengucapan konsonan bilabial /b/ setelah diberikan perlakuan pada penelitian sesi ke-6 anak memperoleh skor 12 
dengan persentase $40 \%$ pada sesi ini anak masih belum mampu mengontrol napas yang keluar dari mulutnya dan terdengar masih samar. Hasil penelitian pada sesi ke-7 dalam kemampuan pengucapan konsonan bilabial /b/ anak memperoleh skor sebesar 15 dengan persentase 50\%, pada sesi ini anak masih belum mampu untuk mengucapkan konsonan bilabial /b/ yang terletak di tengah kata. Persentase anak pada sesi ini mengalami peningkatan daripada sesi sebelumnya.

Sesi ke-8, anak memperoleh skor 16 dengan persentase $60 \%$ pada sesi ini anak masih belum mampu mengucapkan konsonan bilabial /b/ yang terletak di tengah kata, karena dalam sesi ini pengucapan konsonan bilabial/b/ dalam kata anak mengucapkannya masih terputus-putus, terputus oleh konsonan lain. Tetapi, sesi ini mengalami peningkatan daripada sesi sebelumnya. Sesi ke-9 dan sesi ke-10 anak memperoleh skor yang sama sebesar 19 dengan persentase $63 \%$ dalam sesi ini anak sudah mulai baik untuk mengucapkan konsonan bilabial /b/. Napas yang dikeluarkan juga semakin terkontrol dan kuat sehingga untuk mengucapkannya menjadi semakin mudah bagi anak. Penelitian pada sesi ke-11 anak memperoleh skor sebesar 20 dengan persentase $67 \%$, pada sesi ini pernapasan anak mulai membaik dan kuat untuk mengucapkan konsonan bilabial/b/. Napasnya juga semakin terkontrol sehingga untuk mengucapkan konsonan bilabial /b/ menjadi semakin mudah bagi anak.

Baseline 2 (A2). Tahap ini bentuk pengukuran pengaruh dari tahap intervensi yang disebut sebagai tahap baseline $2\left(\mathrm{~A}_{2}\right)$, memungkinkan untuk menarik kesimpulan. Hasil penelitian pada sesi ke-12, anak mampu mengucapkan konsonan bilabial /b/ yang terdiri dari 30 item tes kartu kata yang mengandung konsonan bilabial /b/ terletak di awal, tengah dan akhir dalam kata, jumlah skor yang diperoleh yaitu 17 dengan persentase 57\%. Sedangkan, pada sesi ke-13 sampai ke-15 mendapatkan nilai data yang sama, dalam sesi ini anak mampu mengucapkan konsonan bilabial /b/ dengan jumlah skor 18 dan jumlah persentase $60 \%$.

Pada sesi ke-16 dan sesi ke-17 mendapatkan hasil yang sama, pada sesi ini kemampuan pengucapan konsonan bilabial /b/ anak memperoleh skor 19 dengan persentase $63 \%$ dalam sesi ini mengalami peningkatan dari sesi sebelumnya. Berdasarkan keseluruhan grafik yang diatas maka dapat dilihat kemampuan yang diperoleh anak mengalami peningkatan dari tahap sebelumnya yaitu baseline $1\left(\mathrm{~A}_{1}\right)$ setelah dilakukan intervensi (B). Pada tahap penelitian ini, peneliti hanya memperhatikan anak dalam kemampuan pengucapan konsonan bilabial /b/ dari pengukuran seperti baseline $1\left(\mathrm{~A}_{1}\right)$ dengan 30 item tes kartu kata, karena di dalam tahap ini tidak ada pemberian perlakuan ataupun bantuan. Tahap ini sebagai ukuran pengaruh dari tahap sebelumnya yaitu intervensi terhadap peningkatan pengucapan konsonan bilabial /b/ terhadap anak tunarungu kelas D2/B SLB B/C Paramita Graha Banjarmasin. Secara keseluruhan, grafik hasil pengukuran pada baseline $1\left(\mathrm{~A}_{1}\right)$, intervensi $(\mathrm{B})$, baseline $2\left(\mathrm{~A}_{2}\right)$ dapat divisualisasikan dalam bentuk grafik sebagai berikut: 


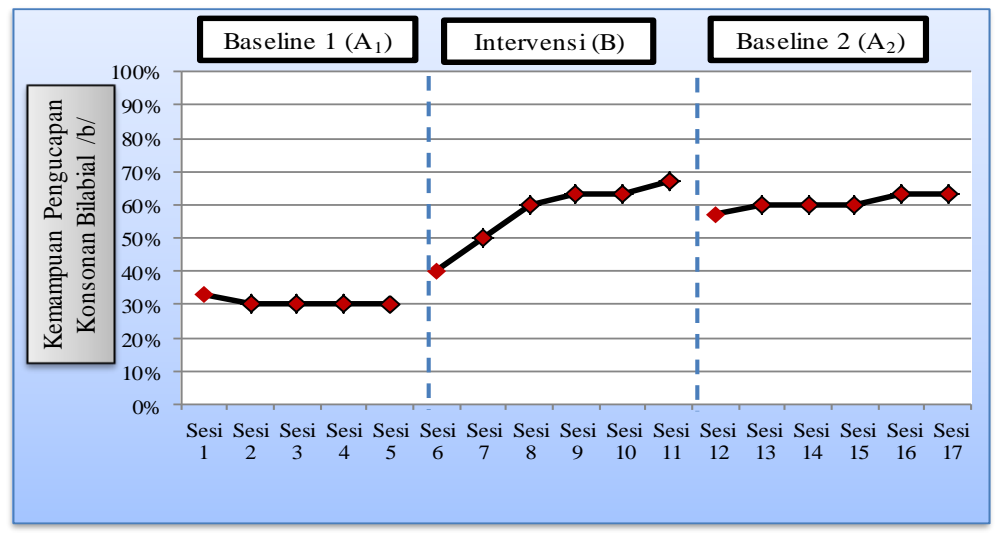

Grafik Hasil Kemampuan Pengucapan Konsonan Bilabial /b/ pada baseline $1\left(\mathrm{~A}_{1}\right)$, intervensi $(\mathrm{B})$, dan baseline $2\left(\mathrm{~A}_{2}\right)$

\section{PEMBAHASAN}

Berdasarkan hasil analisis dan pengolahan data, menunjukkan adanya pengaruh yang positif terhadap latihan pernapasan dengan meniup secara letupan pada bola pingpong untuk meningkatkan pengucapan konsonan bilabial /b/ dalam kata yang terletak di awal, di tengah dan di akhir kata. Penelitian ini dilaksanakan dengan jenis penelitian single subject research (SSR) dengan desain pola A-B-A.

Pada fase baseline $1\left(\mathrm{~A}_{1}\right)$ yang dilaksanakan dengan 5 sesi yaitu untuk mengetahui kemampuan awal pengucapan konsonan bilabial /b/ anak, dengan hasil yang diperoleh dalam kemampuan pengucapan konsonan bilabial /b/ anak yaitu sebesar 30,6\%. Peneliti memperhatikan pengucapan konsonan bilabial /b/ yang diucapkan anak masih terdengar tipis, tanpa letupan, dan napas yang di keluarkannya pendek dan belum terkontrol dengan baik. Sehingga, dalam kemampuan pengucapan konsonan bilabial /b/ napasnya masih tersendat-sendat, dan putus-putus. Sejalan dengan pendapat Fellenddorf dan Black (Sadjaah and Sukarja 1995) yang mengungkapkan bahwa "kesalahan-kesalahan yang sering muncul dari ucapan anak tunarungu yaitu keasalahan akibat terganggunya pernapasan (respiration), phonation (yang berhubungan dengan suara), serta rate (yang berhubungan dengan kecepatan produksi suara)".

Kemudian, pada fase intervensi (B) dilaksanakan dengan 6 sesi, kemampuan pengucapan konsonan bilabial /b/ anak memperoleh persentase 57\%. Hasil pada fase ini menunjukkan bahwa pada fase intervensi memberikan pengaruh yang positif, terlihat dengan adanya pemberian perlakuan yaitu intervensi dalam penelitian dengan latihan pernapasan melalui latihan meniup secara letupan pada bola pingpong, napas anak tunarungu semakin terkontrol dan kuat, sehingga pengucapan anak tunarungu pun semakin membaik. Hal ini sejalan dengan pendapat para pakar (Mansell, 2010; Nakken \& Vlaskamp, 2007; Rahman, 2018; Sadjaah \& Sukarja, 1995; Suprihati, 1996) bahwa "latihan pernapasan merupakan prioritas latihan sejak usia dini, karena pernapasan yang baik dan kuat akan menentukan terbentuknya segala aspek latihan bicara". 
Proses pembentukan bunyi bahasa atau suara memerlukan koordinasi beberapa unsur dengan baik. Pernapasan merupakan unsur penggerak pita suara dan organ bicara yang lain. Tenggorokan merupakan unsur vibrasi dalam pembentukan suara. Sedangkan rongga penutur merupakan kontrol peninggi suara yang digetarkan oleh pita suara. Pernapasan, tenggorokan dan rongga penutur merupakan tiga unsur yang harus saling bekerjasama dalam membentuk bunyi bahasa. Hal ini sejalan dengan pendapat dari Sadjaah dan Sukarja (1995) dan Sardjono dan Kusumo (2005) "bunyi bahasa konsonan terbentuk karena adanya aliran udara ...". Pendapat tersebut menjelaskan bahwa sebuah bunyi bahasa konsonan akan terbentuk apabila adanya aliran udara, dengan adanya latihan meniup secara letupan yang dilakukan sebanyak 6 kali latihan per tiap harinya membuat aliran udara untuk bicara anak semakin lancar dan kuat, sehingga terbentuklah bunyi bahasa konsonan tersebut dikarenakan aliran udara yang lancar untuk bicara.

Selanjutnya, fase baseline $2\left(\mathrm{~A}_{2}\right)$ sebagai bentuk pengukuran atau kontrol tahap intervensi yang disebut sebagai tahap baseline $2\left(\mathrm{~A}_{2}\right)$. Dalam tahap ini dilakukan pengukuran setelah dilakukannya intervensi, mengukur pengaruh intervensi terhadap kemampuan pengucapan konsonan bilabial /b/ anak tunarungu. Hasil penelitian memperoleh persentase sebesar 60,5\%.

Pada penilaian dalam kemampuan pengucapan bentuk konsonan bilabial /b/ yang dibuat peneliti dalam 30 item tes, pengucapan konsonan bilabial /b/ yang semakin membaik daripada fase-fase sebelumnya. Terlihat dari jumlah persentase kemampuan pengucapan konsonan bilabial /b/ yang diucapkan anak, menunjukkan bahwa adanya peningkatan kemampuan pengucapan konsonan bilabial /b/ pada baseline $2\left(\mathrm{~A}_{2}\right)$ dibandingkan dari baseline $\left(\mathrm{A}_{1}\right)$. Hal ini menunjukan adanya pengaruh positif yang diberikan pada fase intervensi, sehingga pada baseline $2\left(\mathrm{~A}_{2}\right)$ menunjukan peningkatan, berhasilnya proses intervensi yang dilakukan dengan latihan pernapasan sehingga anak tunarungu dapat berbicara dengan benar dan mengkontrol keluar masuknya napas agar tidak tesendat-sendat, putus-putus, monoton, melengking, atau tidak jelasnya pengucapan. Sejalan dengan pendapat para pakar (Afiati, 2017; Hernawati, 2007; Sadjaah \& Sukarja, 1995; Winarsih 2010) bahwa "agar anak mampu menghemat napas yang keluar, belajar membesarkan volume untuk meluncurkan bunyi, dan belajar mengkondisikan pernapasan campur untuk keperluan pengucapan”.

\section{KESIMPULAN DAN SARAN}

Berdasarkan hasil penelitian dan pembahasan yang menunjukkan bahwa latihan meniup bola pingpong dapat meningkatkan kemampuan pengucapan konsonan bilabial /b/ pada anak tunarungu kelas D2/B di SLB B/C Paramita Graha Banjarmasin.

Bagi Siswa Tunarungu. Tidak hanya mempelajari atau mengucapkan kejelasan artikulasi untuk meningkatkan kemampuan wicara, namun terus berlatih, sehingga apa yang sudah dipelajari dapat berkembang di kemudian hari.

Bagi Guru. Diharapkan guru dapat memperluas pengetahuan dalam mengembangkan kemampuan wicara anak tunarungu. Agar perkembangan permulaan pertama kali anak di sekolah diberikan stimulus berdasarkan potensi yang masih tersisa pada anak, sehingga potensi yang dimiliki oleh anak dapat berkembang dan dapat membantunya dalam komunikasi sehari-hari terhadap orang pada umumnya tidak hanya selalu menggunakan bahasa isyarat, namun juga keterampilan lain. 
Bagi Sekolah. Diharapkan sekolah lebih fokus dalam pengembangan keterampilan anak, bukan hanya akademik. Namun keterampilan lain seperti pengembangan bina wicara anak dapat dijadikan materi khusus di sekolah guna pengembangan anak.

Bagi Peneliti Lainnya. Diharapkan bisa digunakan dengan sebaik-baiknya sebagai bentuk referensi dalam penanganan anak berkebutuhan khusus, terutama anak tunarungu dalam hal bina wicara.

\section{DAFTAR RUJUKAN}

Afiati, D.H. (2017). Pelaksanaan Bina Wicara Pada Anak Tunarungu di SLB Negeri 2 Bantul (The Implementation of Bina Wicara to Deaf Students in SLB Negeri 2 Bantul. Widia Ortodidaktika 6(5): 449-62.

Arifin, M. (2013). Bina Bicara Berbasis Komunikasi Total Terhadap Kemampuan Bicara Pada Anak Tunarungu Di SMPLB. Jurnal Pendidikan Khusus 3(3).

Arikunto, S. (2019). Prosedur Penelitian. Rineka cipta.

Depdikbud. (2000). Kamus Besar Bahasa Indonesia (KBBI), Edisi Ke 3. Jakarta, Indonesia: Balai Pustaka.

Haenudin, H. (2013). Jakarta: PT Luxima Metro Media Pendidikan Anak Berkebutuhan Khusus Tunarungu.

Hernawati, T. (2007). Pengembangan Kemampuan Berbahasa \& Berbicara Anak Tunarungu. Jurnal JASSI_anakku 7(1): 101-10.

Humaera, S. (2017). Teknik Penanganan Terapi Wicara Untuk Melatih Kemampuan Bahasa Bicara Anak Tunarungu (Studi Kasus Di SDIT Dauroh Curug-Tangerang). Skripsi, Universitas Islam Negeri "SMH" Banten.

Indriati, E. (2015). Kesulitan Bicara \& Berbahasa Pada Anak. Prenada Media.

Isnendes, R. (2005). Semiotika Siliwangi Pada Masyarakat Sunda. Jurnal Bahasa \& Sastra 5(2): 7180.

Mansell, J. (2010). Raising Our Sights: Services for Adults with Profound Intellectual \& Multiple Disabilities. Department of health, London.

Nakken, H. \& Carla V. (2007). A Need for a Taxonomy for Profound Intellectual \& Multiple Disabilities. Journal of Policy \& Practice in intellectual Disabilities 4(2): 83-87.

Poppes, P., Van der Putten, A. J. J., \& Vlaskamp, C. (2010). Frequency \& Severity of Challenging Behaviour in People with Profound Intellectual \& Multiple Disabilities. Research in developmental disabilities 31(6): 1269-75.

Purbaningrum, E. (2008). Modul Bina Persepsi Bunyi \& Bina Bicara. Surabaya: Universitas Negeri Surabaya.

Rahman, A. (2018). Implementasi Kegiatan Ekstrakurikuler Bagi Peserta Didik Tunarungu Di SMPLB. Jurnal Pendidikan Khusus 10(2).

Sadja’ah, E. (2005). Gangguan Bicara Bahasa. Bandung: San Grafika. 
Sadjaah, E. \& Dardjo S. (1995). Bina Bicara, Persepsi Bunyi \& Irama. Bandung: Departemen Pendidikan \& Kebudayaan.

Sardjono, P. \& Pradoto, K. (2005). Pengkajian Sastra. Jakarta: Gramedia Pustaka Utama.

Sunanik, S. (2013). Pelaksanaan Terapi Wicara \& Terapi Sensori Integrasi Pada Anak Terlambat Bicara. Nadwa 7(1): 19-44.

Sunanto, J. K. T. \& Nakata, H. (2005). Pengantar Penelitian dengan Subjek Tunggal. Universitas Tsukuba: Crice.

Tawney, J. W. \& Gast. D. L. (1984). Single Subject Research in Special Education. Columbus, OH: Charles E.

Winarsih, M. (2010). Pembelajaran Bahasa Bagi Anak Tunarungu. Perspektif Ilmu Pendidikan 22 (XIII): 103-13.

Yanti, D. (2012). Penatalaksanaan Terapi Wicara Pada Tuna Rungu. Akrab: ECG. 